California Natural History Guides: 5

\title{
ROCKS AND MINERALS OF THE
}

SAN FRANCISCO BAY REGION

BY

OLIVER E. BOWEN, JR.

Drawings by Helen Laudermilk 
UNTVERSTYY OF GALIFORNLA PRESS

BERKELEY AND LOS ANGELES, CALTFORNIA

(C) 1962 BY THE REGENTS OF THE UNIVERSITY OF CALIFORNIS

SECOND PRINTING, 1966

LUBRARY OF CONGRESS CATALOG CARD NUMBER: 62-17532

PRINTED IN THE UNTTED STATES OF AMGRTCA 